Літус І.О., Свістунов І.В.

\title{
Особливості гістологічної будови рецидивуючих фіброепітеліальних поліпів шкіри у хворих з метаболічним синдромом та цукровим діабетом 2-го типу
}

\author{
Національна медична академія післядипломної освіти імені П.Л. Шупика, м. Київ, Україна \\ irinalitus@gmail.com,svistunov.iv@gmail.com
}

\author{
Литус И.А., Свистунов И.В. \\ Особенности гистологического строения \\ рецидивирующих фиброэпителиальных полипов \\ кожи у больных с метаболическим синдромом \\ и сахарным диабетом 2-го типа \\ Национальная медицинская академия последипломного \\ образования имени П.Л. Шупика, г. Киев, Украина
}

\author{
Litus I.A., Svistunov I.V. \\ Features of the histological structure \\ of recurrent fibroepithelial skin polyps in patients \\ with metabolic syndrome and type 2 diabetes \\ Shupyk National Medical Academy \\ of Postgraduate Education, Kyiv, Ukraine
}

\section{Вступ}

Фіброепітеліальні поліпи шкіри (син. акрохордон, м'яка фіброма, skin tag) є розповсюдженим варіантом неоплазій шкіри, які часто асоційовані 3 ожирінням i цукровим діабетом 2-го типу [5,6]. Зокрема, фіброепітеліальні поліпи у пацієнтів 3 метаболічним синдромом дослідники вважають найпоширенішими дерматозами, разом із стриями, акантозом і підошовним гіперкератозом [3,7].

Фіброепітеліальні поліпи шкіри зустрічаються 3 рівною частотою як у чоловіків, так і у жінок. Частіше всього 3'являються в середньому та похилому віці, у вагітних та людей з надлишком ваги [1]. В деяких випадках фіброепітеліальні поліпи можуть бути предикторами злоякісних утворень шкіри [2]. В літературі є описи гістологічної структури фіброепітеліальних поліпів шкіри [4], але практично відсутні дані про відмінності їх морфологічних ознак у пацієнтів 3 метаболічним синдромом та/або цукровим діабетом 2-го типу та у хворих без такої патології. Разом 3 тим є можливим передбачити такі особливості гістології цих утворень внаслідок метаболічних порушень, вивчення яких може мати важливе прогностичне і практичне значення.

Мета дослідження - вивчити особливості гістологічної будови рецидивуючих фіброепітеліальних поліпів шкіри у хворих 3 метаболічним синдромом та цукровим діабетом 2-го типу.

\section{Завдання, матеріали та методи дослідження}

Завдання дослідження передбачали проведення порівняння гістологічної будови фіброепітеліальних поліпів шкіри у досліджуваних осіб в залежно від наявності метаболічних порушень. Загалом у дослідження було включено 133 пацієнта, які мали більше трьох рецидивуючих фіброепітеліальних поліпів шкіри. Діагноз фіброепітеліального поліпу шкіри (папілома, папілома фіброэпітеліальна, фібропапіллома, м'яка фіброма, акрохордон) встановлювався відповідно до МКХ-Х (D23.9).

Пацієнти були розподілені на три групи. Першу групу склали пацієнти без метаболічних порушень в кількості 62 осіб (контрольна група), до другої та третьої груп увійшли відповідно пацієнти 3 верифікованим метаболічним синдромом (49 осіб) та хворі на цукровий діабет 2-го типу (22 особи), загалом хворих 3 метаболічними порушеннями (друга i третя група) нараховувалось 71 особа.

Видалені у пацієнтів фіброепітеліальні поліпи шкіри досліджувались в повному обсязі морфологічним методом (мікроскопія гістологічних препаратів). Отриманий біоматеріал фіксували у $10 \%$ розчині забуференого нейтрального формаліну. Проводку біоматеріалу (дегідратацію та просочування парафіном) здійснювали у автоматизованих гістопроцесорах (Milestone LOGOS Microwave Hybrid Tissue Processor, Milestone, Italy). Після проводки проводили заливку матеріалу у парафін з виготовленням парафінових блоків на станціях заливки та виготовлення парафінових блоків Thermo Scientific HistoStar (Thermo Fisher Scientific, USA).

Гістологічні зрізи товщиною 4 мкм виготовляли на напівавтоматизованому ротаційному мікротомі Thermo Scientific HM 340E. Препарати забарвлювали гематоксиліном та еозином 3 використанням автоматизованого коверстейнера Dako CoverStainer (Agilent, USA). При мікроскопічному дослідженні матеріалу використовували мікроскоп NIKON ECLIPSE E200 (NIKON CORPORATION, Japan).

Обробка результатів проводилась медикостатистичним методом за допомогою програми «Minitab 16». Для перевірки розподілу на нормальність 
використовували тест Колмогорова-Смірнова; порівняльний аналіз центральних тенденцій двох незалежних вибірок здійснювали 3 використанням U-критерію Манна-Уїтні і середніх величин двох незалежних вибірок за критерієм Стьюдента (p). Кількісні змінні представлені у вигляді відносних величин (\%) та середніх значень ( $\overline{\mathrm{X}}$ ) і середньоквадратичних відхилень (SD) або 95\% довірчим інтервалом для параметричних методів, і медіани (Ме) 31 (Q1) і 3 (Q3) квартилем або 95\% довірчим інтервалом для непараметричних даних.
Робота виконувалась в рамках планових науководослідних тем наукових робіт кафедри дерматовенерології Національної медичної академії післядипломної освіти імені П.Л. Шупика. У всіх пацієнтів отримано добровільну письмову згоду на участь в науковому дослідженні.

\section{Результати дослідження та їх обговорення}

Аналіз окремих демографічних характеристик пацієнтів засвідчив, що за віком і статтю контрольна (перша) та дослідні (друга і третя) групи достовірно не відрізнялися (табл.).

Таблиця. Вікові та статеві характеристики дослідної та контрольної груп

\begin{tabular}{|c|c|c|c|}
\hline Характеристики & $\begin{array}{c}\text { Дослідні групи } \\
\text { (усього } 71 \text { паціснт) }\end{array}$ & $\begin{array}{c}\text { Контрольна група } \\
\text { (62 паціснти) }\end{array}$ & $\begin{array}{c}\text { Статистичні } \\
\text { критерії }\end{array}$ \\
\hline Середній вік $\overline{\mathrm{X}}_{ \pm \mathrm{SD}}$ (роки) & $45,63 \pm 12,98$ & $46,27 \pm 10,73$ & $\mathrm{p}=0,756$ \\
\hline $\begin{array}{l}\text { Розподіл пацієнтів за статтю, } \\
\text { абс. }(\%) \text { : } \\
\text { чоловіча } \\
\text { жіноча }\end{array}$ & $\begin{array}{l}36(51 \%) \\
35(49 \%)\end{array}$ & $\begin{array}{l}29(47 \%) \\
33(53 \%)\end{array}$ & $\begin{array}{c}\chi 2=0,077 \\
p=0,781\end{array}$ \\
\hline
\end{tabular}

Встановлено, що форма та розмір було визначено класичну гістологічну картину (рис. 1). фіброепітеліальних поліпів шкіри пацієнтів виокремлених Досліджувані утворення мали характерну поліпоподібну груп значно варіювали. Проте середній розмір форму, не містили придатків шкіри (волосся та залоз), а біоматеріалів не мав статистично значущих розбіжностей отже, були утворені за рахунок інтерфолікулярного в групах, і становив у пацієнтів: контрольної групи - компартменту шкіри. Окрім грибоподібних



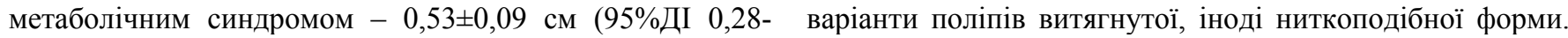

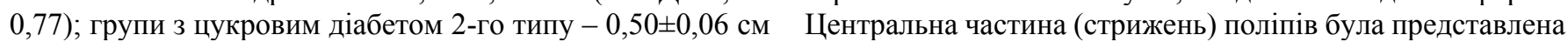
(95\% ДІ 0,32-0,76).

При мікроскопічному дослідженні фібро- тканиною, що містила крупні, подекуди дилятовані епітеліальних поліпів шкіри пацієнтів контрольної групи судини.

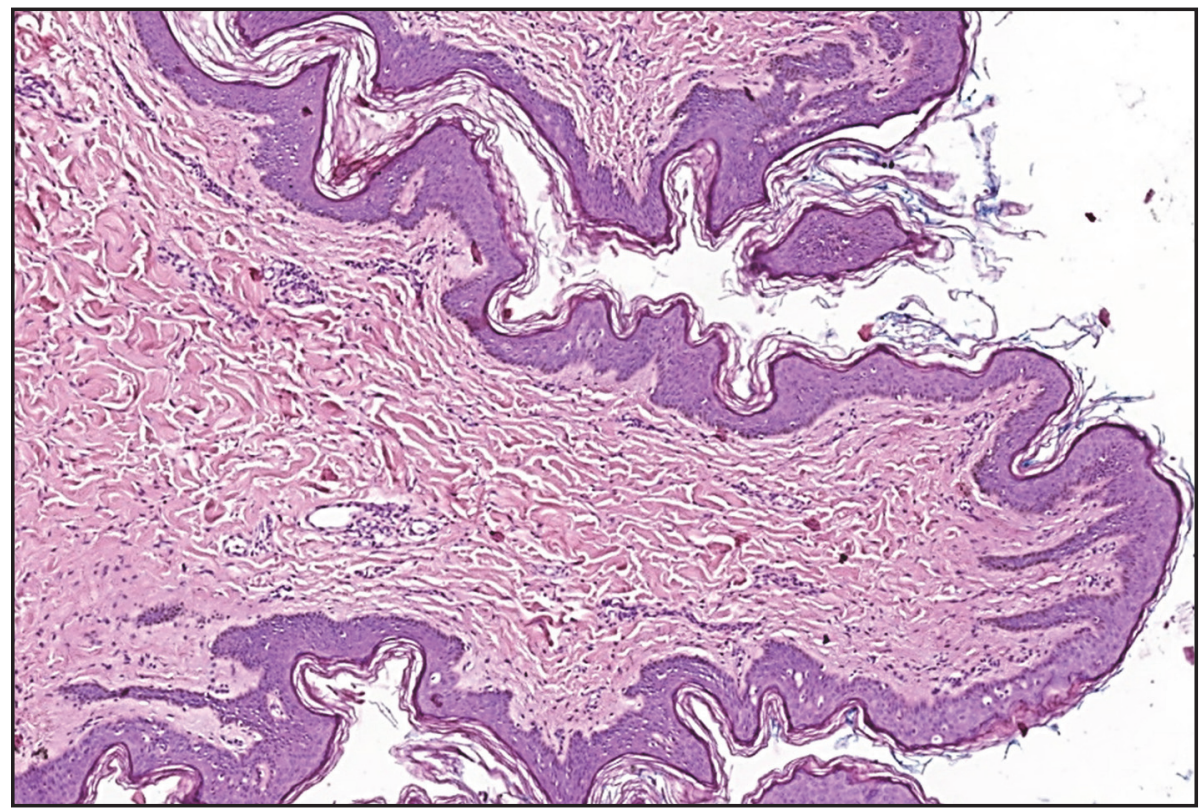

Рис. 1. Будова фіброепітеліального поліпу у пацієнтів контрольної групи. Забарвлення гематоксиліном та еозином. 3б. 50. 
Поверхня фіброепітеліальних поліпів шкіри була вкрита багатошаровим плоским зроговілим епітелієм, в якому подекуди визначалися реактивні зміни. Дерма в межах фіброепітеліальних поліпів зберігала шарову будову. Під епідермісом визначався сосочковий шар дерми, утворений пухкою волокнистою сполучною тканиною з численними судинами мікроциркуляторного русла. В більшості випадків поверхня поліпу була нерівна 3 формуванням вторинних вип'ячувань - сосочків, які мали переважно покату форму.

При аналізі епідермо-дермальної межі виявлялися як ділянки формування невиразних вторинних сосочків дерми та гребінців епідермісу, так і зони згладженої епідермо-дермальної межі. В межах сітчастого шару визначалася щільна волокниста неоформлена сполучна тканина, в центральній частині фіброепітеліальних поліпів визначалися розширені кровоносні судини, переважно неправильної форми 3 тонкими стінками. Сполучна тканина була 3 ознаками набряку та розпушення колагенових волокон, більше - в центральній частині поліпу. Судини поверхневого судинного сплетення в межах поліпу були нерівномірними за діаметром, місцями широкі та розгалужені. В окремих випадках периваскулярна зона мала ознаки помірного набряку та слабкої лімфогістіоцитарної інфільтрації.

При дослідженні гістологічної будови фіброепітеліальних поліпів шкіри у пацієнтів другої та третьої груп було зафіксовано значний папіломатоз поверхні поліпів за рахунок формування численних виразних розгалужених вторинних і третинних сосочків (рис. 2).
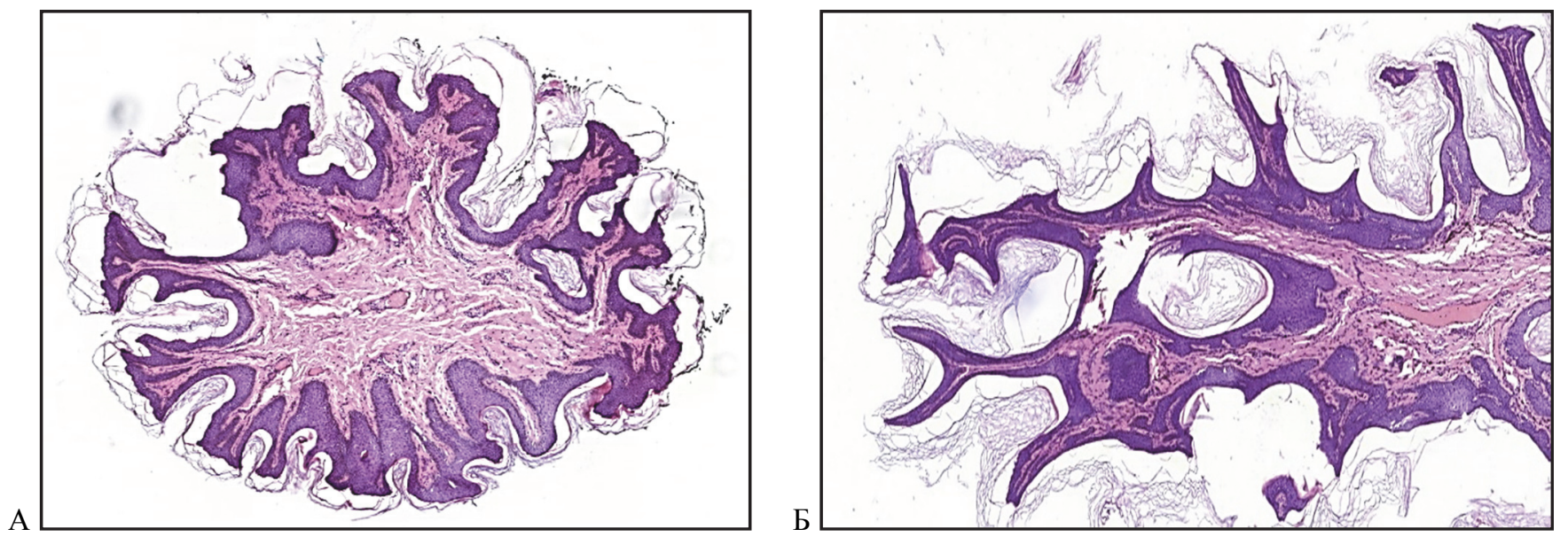

Рис. 2. Гістологічна будова фіброепітеліальних поліпів шкіри пацієнтів з метаболічним синдромом (А) та з цукровим діабетом 2-го типу (Б). Папіломатоз поверхні фіброепітеліальних поліпів шкіри асоційований з виразними розгалуженими вторинними сосочками. Забарвлення гематоксиліном та еозином. 3б. 20.

Частина їх була грибоподібної форми, проте переважали видовжені або конусоподібні вторинні вирости. Епідерміс мав ознаки помірного або виразного акантозу, в ряді випадків визначалися ознаки гіперкератозу, формування рогових псевдокіст. За рахунок цих змін значно зростала площа епідермо-дермальної межі, що по суті відбиває зміну міжтканинних відносин у межах фіброепітеліальних поліпів при інсулінорезистентності і може бути наслідком посилення проліферації клітин епідермісу та сосочкового шару дерми в межах поліпів.

Другою особливістю будови фіброепітеліальних поліпів шкіри у хворих другої та третьої груп виявлено значну кількість судин і наявність судинних мальформацій 3 переважанням тонкостінних судин нерівномірного діаметру та периваскулярного набряку навколо судин поверхневого судинного сплетіння та в субепідермальному компартменті.
Третьою особливістю будови фіброепітеліальних поліпів шкіри у хворих на метаболічний синдром та цукровий діабет 2-го типу встановлено значно більш виразну лейкоцитарну інфільтрацію, що відображало наявність хронічного запального процесу (рис. 3).

Лейкоцитарна інфільтрація була помірною чи виразною й визначалася як у периваскулярному компартменті, так і в сосочковому шарі дерми поліпів поблизу від епідермісу; при цьому інфільтрати були представлені переважно клітинами лімфогістіоцитарного ряду. Місцями ділянки лімфогістіоцитарної інфільтрації були асоційовані з менш вираженим набряком та виразним фіброзуванням строми поліпу.

Таким чином, результати нашого дослідження чітко ідентифікували морфологічні патерни фіброепітеліальних поліпів шкіри, які можуть використовуватись як додаткові критерії, за допомогою яких лікар-дерматолог може запідозрити наявність метаболічних порушень у даного контингенту пацієнтів. 


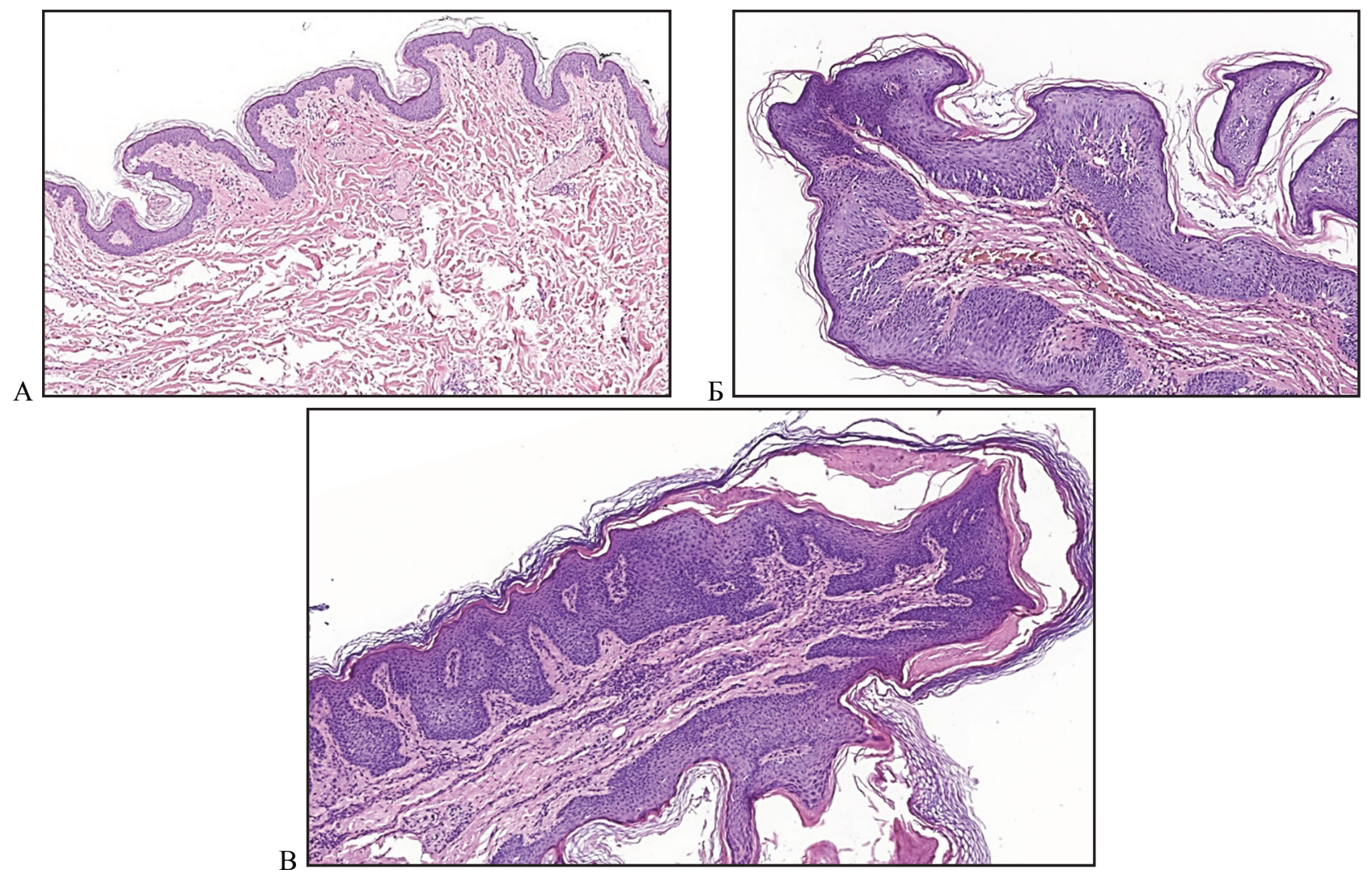

А - контрольна (перша) група, Б - група пацієнтів з метаболічним синдромом (друга група), В - група пацієнтів 3 цукровим діабетом 2-го типу (третя група)

Рис. 3. Різна виразність лімфогістіоцитарної інфільтрації в межах фіброепітеліальних поліпів у пацієнтів контрольної та дослідних груп.

Забарвлення гематоксиліном та еозином. Зб. 50.

\section{Висновки}

Фіброепітеліальні поліпи шкіри у хворих на метаболічний синдром та цукровий діабет 2-го типу мають характерні специфічні особливості гістологічної будови: ознаки значно вираженого папіломатозу поверхні поліпів за рахунок формування численних виразних розгалужених вторинних та третинних сосочків; значну кількість судин наявність судинних мальформацій; значно більш виразну лейкоцитарну інфільтрацію в порівнянні з гістологічною структурою аналогічного біоматеріалу пацієнтів без метаболічних порушень.

Отримані результати можуть бути використані в практиці лікарів-дерматологів як додатковий критерій діагностики можливих метаболічних порушень у хворих 3 фіброепітеліальними поліпами шкіри.

\section{References}

1. Goryachkina M. V., Belousova T. A. Dermatologiya. Dobrokachestvennyye epitelial'nyye opukholi kozhi. Prilozheniye k zhurnalu Consilium Medicum. 2014. № 4. S. 20-23.

2. Aksoy B., Aksoy H M. Keratoacanthoma in an acrochordon. Turkderm-Turk Arch Dermatol Venereology. 2017. № 51. P. 24-25.

3. Comparison of cutaneous manifestations in diabetic and nondiabetic obese patients: A prospective, controlled study / Ozlu E. et al. North Clin Istanb. 2018. May 21;5 (2). P. 114-119. doi: 10.14744/nci.2017.68553.

4. Cutaneous Manifestations of Diabetes Mellitus / M. Duff et al. Clin Diabetes. 2015. Jan; 33 (1). P. 40-48. doi: $10.2337 /$ diaclin.33.1.40.

5. Higgins J., Maner M., Douglas M. Diagnosing Common Benign Skin Tumors / Am Fam Physician. 2015. Oct 1; 92 (7). P. 601-607.

6. Tapaswini Tripathy, Bhabani S.T.P. Singh, R. Kar. Association of Skin Tag with Metabolic Syndrome and its Components: A Case-control Study from Eastern India. Indian Dermatol Online J. 2019. May-Jun; 10 (3). P. $284-287$. 
7. Uzuncakmak T.K., Akdeniz N., Karadag A.S. Cutaneous manifestations of obesity and the metabolic syndrome. Clin Dermatol. 2018. Jan-Feb; 36 (1). P. 81-88. doi: 10.1016/j.clindermatol.2017.09.014. Epub 2017. Sep 8.

Дата надходження рукопису до редакції: 27.01.2020 р.

\begin{abstract}
Мета: вивчити особливості гістологічної будови рецидивуючих фіброепітеліальних поліпів шкіри у хворих 3 метаболічним синдромом і цукровим діабетом 2-го типу.

Матеріали та методи. Матеріалами дослідження слугували фіброепітеліальні поліпи шкіри, видалені у 133 пацієнтів, розподілених на три групи: без метаболічних порушень (контрольна група, 62 особи); 3 верифікованим метаболічним синдромом (49 осіб); з цукровим діабетом 2-го типу (22 особи). Використані методи дослідження: морфологічний (мікроскопія гістологічних препаратів); порівняльного аналізу; медико-статистичний.
\end{abstract}

Результати. Виявлено, що фіброепітеліальні поліпи шкіри у хворих на метаболічний синдром і цукровий діабет 2-го типу мають відмінності гістологічної будови в порівнянні з аналогічним біоматеріалом пацієнтів без метаболічних порушень: виражений папіломатоз поверхні поліпів, значна кількість судин і судинних мальформацій, виражена лейкоцитарна інфільтрація.

Висновки. Особливості гістологічної будови фіброепітеліальних поліпів шкіри можуть використовуватись як додаткові критерії для діагностики можливих метаболічних порушень у пацієнтів.

Ключові слова: фіброепітеліальні поліпи шкіри, метаболічний синдром, цукровий діабет 2-го типу, гістологічна будова.

Цель: изучить особенности гистологического строения рецидивирующих фиброэпителиальных полипов кожи у больных с метаболическим синдромом и сахарным диабетом 2-го типа.

Материалы и методы. В качестве материалов исследования использованы фиброэпителиальные полипы кожи, удаленные у 133 пациентов, распределенных на три группы: без метаболических нарушений (контрольная группа, 62 человека); с верифицированным метаболическим синдромом (49 человек); с сахарным диабетом 2-го типа (22 человека). Методы: морфологический (микроскопия гистологических препаратов); сравнительного анализа; медико-статистический.

Результаты. Выявлено, что фиброэпителиальные полипы кожи у больных метаболическим синдромом и сахарным диабетом 2-го типа имеют отличия в гистологическом строении по сравнению с аналогичным биоматериалом пациентов без метаболических нарушений: выраженный папилломатоз поверхности полипов, значительное количество сосудов и сосудистых мальформаций, выраженную лейкоцитарную инфильтрацию.

Выводы. Особенности гистологического строения фиброэпителиальных полипов кожи могут использоваться как дополнительные критерии для диагностики возможных метаболических нарушений у пациентов.

Ключевые слова: фиброэпителиальные полипы кожи, метаболический синдром, сахарный диабет 2-го типа, гистологическое строение.

The aim: to study the features of the histological structure of recurrent fibroepithelial skin polyps in patients with metabolic syndrome and type 2 diabetes.

Materials and methods. Fibroepithelial skin polyps were removed in 133 patients, divided into three groups: without metabolic disturbances (control group, 62 people); with verified metabolic syndrome (49 people); with type 2 diabetes (22 people). Methods: morphological (microscopy of histological preparations); comparative analysis; medical and statistical.

Results. Fibroepithelial skin polyps in patients with metabolic syndrome and type 2 diabetes mellitus have differences in the histological structure compared to the same biomaterial of patients without metabolic disorders: severe papillomatosis of the polyps surface, a significant number of vessels and vascular malformations, severe leukocyte infiltration.

Conclusion: the features of the histological structure of fibroepithelial skin polyps can be used as additional criteria for the diagnosis of possible metabolic disorders in patients.

Key words: fibroepithelial skin polyps, metabolic syndrome, type 2 diabetes mellitus, histological structure.

Конфлікт інтересів: відсутній.

Conflicts of interest: authors have no conflicts of interest to declare.

\title{
Відомості про авторів
}

Літус Ірина Олександрівна (контактна особа) - аспірант кафедри дерматовенерології Національної медичної академії післядипломної освіти імені П.Л. Шупика; м. Київ, вул. Богатирська 32. +380 (50) 330-31-87, ORCID 0000-0002-5218-7095, irinalitus@gmail.com.

Свистунов Ігор Ваніфатійович - д. мед. н. професор; професор кафедри дерматовенерології Національної медичної академії післядипломної освіти імені П.Л. Шупика; м. Київ, вул. Богатирська 32.

svistunov.iv@gmail.com. 